\title{
Web-Based Expert System for Diagnosis of Date Palm Diseases
}

\author{
Khdega A.Yosef Galala \\ Department of Computer Science, College of Education, Al Jufrah University, Libya
}

\begin{abstract}
The main aim of the study is to develop advisory system for the early diagnosis of date palm diseases. The web based expert system presented in this work is divided into two aspects: advisory system and information system. This system is the rule based agricultural system and it covers five fungi diseases occurring in the date palm. Knowledge base in this system consists of data integrated from a variety of date palm knowledge. This intelligent system was developed by using the PHP as the web programming language. The result of the diagnosis process showed the expert system running well in diagnosing the date palm's diseases. It could be concluded that, this system can be a bit much better to help farmers to diagnosing date palm diseases early and it works as an assistant tool to produce a better quality of date palm product.
\end{abstract}

\section{Introduction}

This study aimed to develop an expert advisory system for the early diagnosis of date palm diseases. Thus, this section introduces an overview of the basic background of the study. The following paragraphs highlighting the agricultural knowledge about the date palm as well as expert systems in domain of agricultural diagnosis.

Date palm is of economic importance, it is a primary sector of many countries and represents a source of income for many farmers in countries in North Africa such as Libya, Tunisia, Morocco, Algeria, etc. In Libya, dates are the most an important traditional crop and their trees grow in large area. There are more than 6 million date palms, produces about 400 cultivars [1]. In modern times, palm diseases are among the major factors affecting products quality and causes serious damage to trees. The date palms are attack by numerous serious pests; whether fungi, arthropods, nematode or phytoplasma [2]. In general, date palm diseases can be divided into the three major types: fungal diseases, phytoplasmic diseases and diseases of unknown cause. Fungi are known as the most causal pathogens on date palm trees. Most of fungal diseases are dangerous and causes serious damage to date palm plantation. The nowadays sudden decline became a real threat for current date palm cultivation in which need a lot of effort and costing a lot of money to control. The following paragraph highlights on some of the most common diseases of this type.
One of the most an effect disease on date palm is Inflorescence Rot, commonly known as Khamedj. It is a serious disease to date palm in many countries such as Libya, Morocco and Tunisia. The major symptoms of the disease are brown or rust colored area on the external surface of unopened spathes; partial or complete destruction of flowers [3]. Another serious fungal disease on date palm is Black Scorch. Dark brown-black scorch on the leaves, inflorescence blight, heart or trunk rot, foliage with scorched appearance are usually the common symptoms of this disease. Graphiola Leaf Spot is a very common diseases in date palm. The main symptoms of the disease appear as small spots on both sides of the pinnae leaves and a small yellow/brown spore masses on leaves [4].

Expert systems have been implemented successfully in almost every domain of human activities. The most important areas where an expert system was implemented efficiently are agriculture, medicine, education, environment, etc. In an agricultural domain, the expert system started to be existing at the end of 1970s. After nearly 30 years development, its application domain has spread to cover the various fields of agriculture in the area of diseases diagnosis and pest controls, water scheduling, soil preparation, weed management, etc. With the recent growth, farmers require advice or expert knowledge to take decision in different aspect of in the agriculture domain to get a high yield [5]. However, in an agricultural domain, knowledge and expertise in making decisions exists, but the major problem is making it available to the large number of growers [6]. Expert systems introduce as a powerful tool to prove efficiently and effectively advice to growers anytime and anywhere [7]. Nowadays, there is some expert systems in the agriculture domain are available, one of the successful expert systems existing in this domain is a web-based sweet orange crop expert system. It is a rule based expert system and involves two main aspects one is sweet orange advisory system and the other is sweet orange information system [8]. More recently, an objectoriented expert system for diagnosis of date palms fungal diseases was presented [9]. Another system is a web-based tomato crop expert information system, it contains two main parts, tomato crop expert system and tomato information system [10].

Based on the above literature, there is a great need for an initiative expert system which may suggest suitable solutions to the farmers. Thus, the 
primary goal of this study is to develop an expert system for diagnosis common date palm fungal diseases. The domain of the system is limited to the following disease: Inflorescence rot, Fusarium wilt, Graphiola leaf spot, Black scorch and Diplodia disease. This system could assist the growers to determine the proper diagnosis as well as for proper advice for treatment for those diseases. Furthermore, user could get more knowledge and experience from this system. The next paragraphs will explain in detail the system proposed in this study.

\section{The proposed diagnostic system}

This section presents an overview of proposed system. The new system has three critical components which are knowledge base, the inference engine and the user interface. Each of these components is described in detail below:

\subsection{The knowledge base}

The knowledge for this study was collected from different sources, the first primary source is the agricultural knowledge of experts in domain and experienced growers. It was done through direct interviews with them. The second source is from relevant specialized agriculture books which is really aimed as a reference for scholars in the field of palm agriculture. In addition, some useful information from electronic agricultural websites was used. The information obtained from different sources was analyzed and classified. However, to ensure the reliability and integrity of data, it was again corroborated by experts. Finally, representation of knowledge in the knowledge base for easy converted into the programming languages.

\subsection{The inference engine}

The proposed system is the rule-based system which much of the knowledge is represented as rules. The knowledge of this system was represented in the form of the decision tree as shown in Figure 1. The production rules (IF-THEN rules) in this system were derived from the decision tree with apply techniques of forward chaining to represent the knowledge.

Table 1 explains about the date palm diseases symptoms which it starts from S1 to S17. While Table 2 shows decision tree of date palm diseases which the proposed system could diagnose, and it starts from D1 to D6.

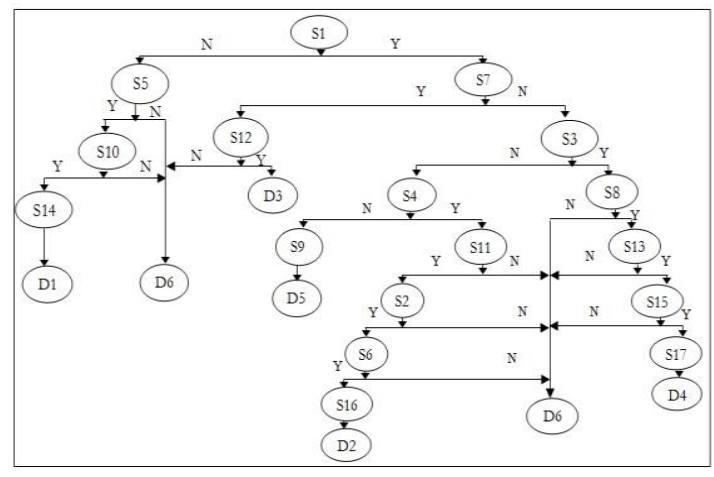

Figure 1. Symptoms decision tree

Table 1. Decision tree symptoms description

\begin{tabular}{|c|c|c|}
\hline No & Code & Description \\
\hline 1 & S1 & $\begin{array}{l}\text { The initial symptoms are observed on the } \\
\text { oldest leaves. }\end{array}$ \\
\hline 2 & $\mathrm{~S} 2$ & $\begin{array}{l}\text { The death of one-sided of the fronds from } \\
\text { bottom to top }\end{array}$ \\
\hline 3 & S3 & Irregular block spots on leaves \\
\hline 4 & S4 & $\begin{array}{l}\text { Yellowish-brown streaks extend along the } \\
\text { leaf base }\end{array}$ \\
\hline 5 & S5 & $\begin{array}{l}\text { Brownish or rusty-coloured area on the } \\
\text { external surface of unopened spathes }\end{array}$ \\
\hline 6 & S6 & $\begin{array}{l}\text { The death of the other side of the fronds } \\
\text { from top to bottom }\end{array}$ \\
\hline 7 & S7 & $\begin{array}{l}\text { Yellow } \backslash \text { brown } \backslash \text { black spots on both sides } \\
\text { of the leaf blade. }\end{array}$ \\
\hline 8 & S8 & $\begin{array}{l}\text { Black scorch on the leaves OR } \\
\text { inflorescence malformation }\end{array}$ \\
\hline 9 & S9 & Death of suckers \\
\hline 10 & S10 & $\begin{array}{l}\text { The inflorescences become dry and covered } \\
\text { with powdery fructify cations of the fungus. }\end{array}$ \\
\hline 11 & S11 & $\begin{array}{l}\text { A reddish-brown or dark-brown stripe along } \\
\text { the midrib of the leaves }\end{array}$ \\
\hline 12 & S12 & $\begin{array}{l}\text { A small dark brown spore masses OR short, } \\
\text { light-colored filaments is emerging on the } \\
\text { infected leaves }\end{array}$ \\
\hline 13 & S13 & Rot of heart or trunk OR rot of bud \\
\hline 14 & S14 & Partial or complete destruction of flowers \\
\hline 15 & S15 & Partial or complete necrosis of the tissues \\
\hline 16 & S16 & $\begin{array}{l}\text { The death of the affected frond in a short } \\
\text { time }\end{array}$ \\
\hline 17 & S17 & $\begin{array}{l}\text { Death of the central cluster leaves OR } \\
\text { bending head }\end{array}$ \\
\hline
\end{tabular}

Table 2. Decision tree of date palm disease

\begin{tabular}{|c|c|l|}
\hline No & Code & Description \\
\hline 1 & D1 & Inflorescence rot (Khamedj) \\
\hline 2 & D2 & Fusarium Wilt \\
\hline 3 & D3 & Graphiola leaf spot \\
\hline 4 & D4 & Black scorch \\
\hline 5 & D5 & Diplodia \\
\hline 6 & D6 & Ineffective \\
\hline
\end{tabular}

At the beginning, the system will ask about the infected part of the tree such as leaves, root, etc. Then the system requests the user to determine the 
type of infection such as spots, rot, etc. If the infection type has common symptom such as a spot, the system requests the user to identify the particular characteristics of the spot such as brown, irregular, brownish yellow, etc. However, according to the user's responses the system continues to move forward from the current state to the goal state, which represents one of the date palm diseases or other information such as ineffective.

If the system is able to obtain the right diagnosis then the system will successfully conclude and it will display the results of the consultation, includes the disease name (such as Khamedj, Graphiola leaf spot, Black scorch, etc), causal agent such as Mauginiella scattae Cav, Graphiola phoenicis (Moug), Ceratocystis paradoxa (Hohn) and the brief explanation about disease management and control. Otherwise, the system will display an appropriate error message. Below an example of one rule that constructed on the knowledge base of the proposed system.

If (Leaves are the infected part $=$ YES) AND (irregular block spots on leaves = YES) AND (black scorched on the leaves $=$ YES OR leaf malformation $=$ YES) AND (partial or complete necrosis of the tissues = YES) AND (heart or trunk rot $=$ YES) AND (death of the central cluster leaves = YES) THEN The Black Scorch Disease.

\subsection{Web-based user interface}

In the current system, the web interface was well designed and built using the PHP language and supported by Java script and CCS. MYSQL was selected as system relational database. A userfriendly software has been developed which can diagnose and prescribe solutions to the treatment of date palm diseases anytime and anywhere. It was carried out with some features to facilitate and support its functions such as an explanation facilities, it can also provide spectrum for information with images about date palms and their diseases such as disease management and control, how selecting a palm tree to plant, planting date palm tree, watering and fertilizing the soil, pollinating, climatic requirements of date palm and many more. The system starts by displaying its home page as shown in Figure 2.

Figure 3 shows diagnosis page, where the system starts diagnosis process to obtain particular solution.

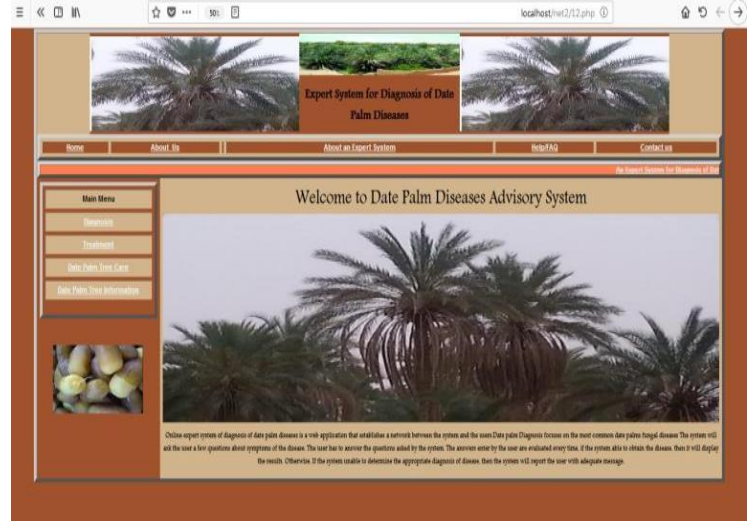

Figure 2. Home page of the system

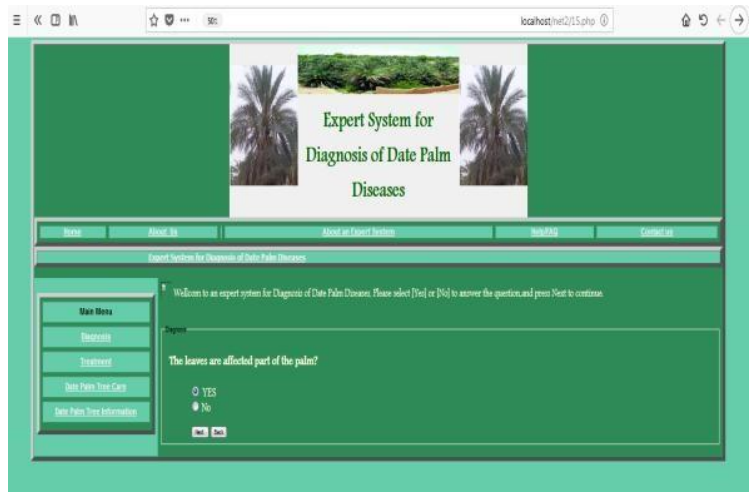

Figure 3. Diagnosis page

Figure 4 shows a diagnosis result page. It shows the name of the disease, causal agent and disease management.

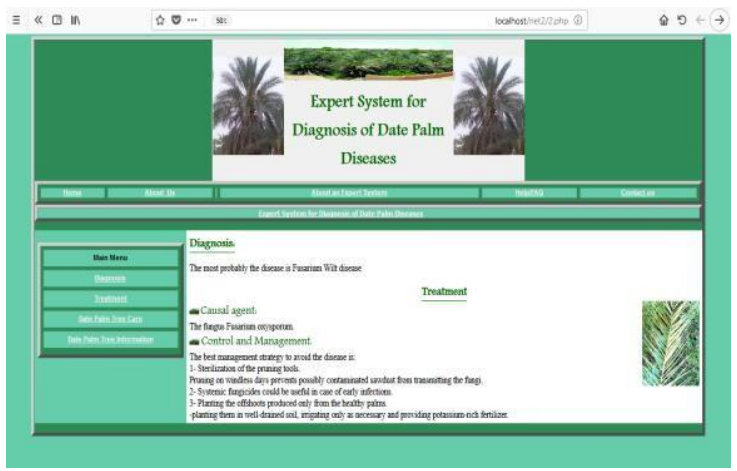

Figure 4. Diagnosis result page

The main purpose of date palm trees care page is to provide the basic expertise needed for taking care of the date palm. It also introduces brief necessary information to successfully plant to raise the production of good dates. Figure 5 shows an example when the user chooses to search about planting palm shoots topic. 


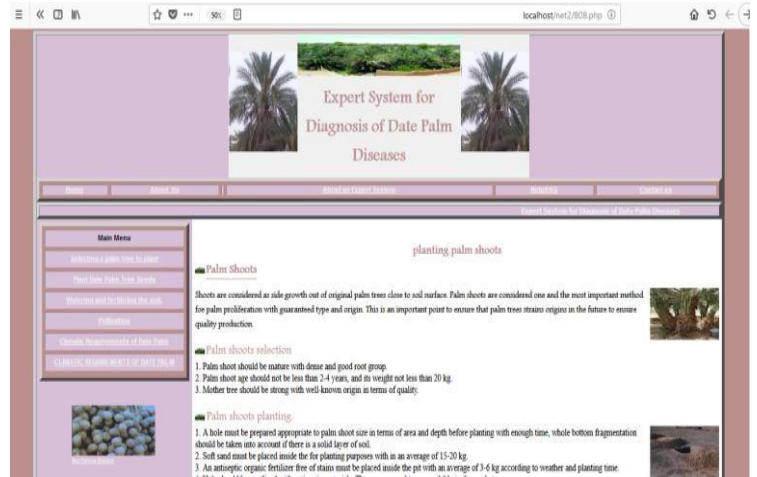

Figure 5. Example of date palm trees care

If a user clicks a date palm tree information button, the corresponding screenshot in Figure 6will be displayed which contains brief information about date palm.

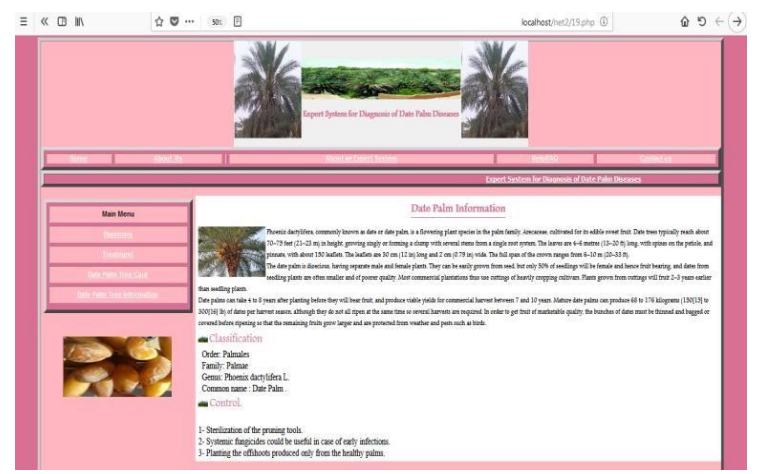

Figure 6. Date palm information page

\section{Results}

After the system was created and was ready, the testing process was being conducted to evaluate the system performance. This step was achieved by testing the system practically with some samples. The results given by the system have been validated by domain experts. The results indicated that the system succeeded in estimating the correct diagnosis.

\section{Conclusion}

In this work, web expert system was established. The main objective of it was to provide a fast solution for user to early detect the date palm's diseases. The contribution of this study will be helping farmers to control the problems in their date palm earlier. For future work, the domain of the system will be extended to accommodate new types of date palm diseases.

\section{References}

[1] M. L. Racchi and et al., "Genetic characterization of Libyan date palm resources by microsatellite markers", 3 Biotech, Vol.4, pp. 21-32, 2014.
[2] Djerbi, M., "Bayoudh disease in North Africa, history, distribution, diagnosis and control", Date Palm Jounal, Vol.1, pp.153-197, 1982.

[3] Samir K.Abdullah, L.V.Lopez Lorca and H.B.Jansson, "Diseases of date palms ( phoenix dactylifera L.)," Basrah Journal for Date Palm Researches, Vol.9, 2010.

[4] Abbas, E.H and Abdulla, A.S., "First report of false smut disease caused by graphiola phoenicis on date palm trees in Qatar, " the British Society for Plant Pathology (BSPP), 14 Jun 2004.

[5] Fahad Shahbaz Khan and et al., "Dr. Wheat: A Webbased expert system for diagnosis of diseases and pests in Pakistani wheat", Proceedings of the World Congress on Engineering WCE, Vol.1, pp.549-554, July 2008.

[6] John Durkin, "Application of expert systems in the sciences", The Ohio Journal of Science, Vol.90, pp. 171179, December 1990.

[7] V.K. Yadav and et al., "Maize AGRIdaksh: a farmer friendly device”, Indian Res. J. Ext. Edu, Vol.12, pp.1317, September 2012.

[8] M.S. Prasad Babu, J. Anitha and K. Hari Krishna, "A web based sweet orange crop expert system using rulebased system and artificial bee colony optimization algorithm", International Journal of Engineering Science and Technology, Vol. 2, pp. 2408-2417, June 2010.

[9] M. Ayman Al-Ahmar, "An object-oriented expert system for diagnosis of fungal diseases of date palm", International Journal of Soft Computing, Vol.4, pp. 201207, 2009.

[10] Prasad Babu M.S., Ramana Murty N.V., and Narayana, S.V.N.L., "A web based tomato crop expert information system based on artificial intelligence and machine learning algorithms, "International Journal of Computer Science and Information Technologies, Vol.1, pp. 6-15, 2010. 